\title{
Leader-Member Exchange and Superior-Subordinate Communication Behavior: A Case of a Malaysian Organization
}

\author{
HASSAN ABU BAKAR \& BAHTIAR MOHAMAD \\ Faculty Of Communication and Modern Languages \\ Universiti Utara Malaysia \\ IRAN HERMAN \\ Faculty of Social Development and Humanities \\ Universiti Utara Malaysia
}

\begin{abstract}
This paper attempts to test the quality of relationship between superiors and subordinates as indicated in leader-member exchange (LMX) theory on superior communication behavior. The results of this study indicate that there are no significance differences between out-group and in-group members. However when in-group members were compared to mid-group members the result reveals significance differences between these two groups.
\end{abstract}

\begin{abstract}
ABSTRAK
Artikel ini cuba menguji kualiti jalinan hubungan antara ketua dan subordinat mereka seperti yang dikemukakan dalam teori penukaran pemimpin-anggota (LMX) terhadap gelagat komunikasi ketua. Hasil kajian menunjukkan tidak terdapat perbezaan yang signifikan antara responden yang dikategorikan dalam kumpulan luar (out-group) dan kumpulan dalam (in-group). Walau bagaimanapun, terdapat perbezaan yang signifikan antara kumpulan pertengahan (mid-group) dengan kumpulan dalaman (ingroup) terhadap gelagat komunikasi ketua mereka.
\end{abstract}

\section{INTRODUCTION}

The superior-subordinate relationship is a social system that functions within the larger system of the work group. This relationship exists not in isolation but is rooted within the group (Jablin \& Krone, 1994). As such, superior-subordinate communication is very important to the organization's overall communication effectiveness. Research has shown that between 50 and 90 percent of a manager's time may be spent communicating (Mintzberg, 1978). Much of this time is spent in face-to-face communication about work with subordinates. Jablin (1979) defined superior-subordinate communication as an exchange of infor- mation and influence between organizational members and at least one of whom has formal (as defined by official organizational sources) authority to direct and evaluate the activities of other organizational members.

Most organizational communication textbooks list several types of communication that can take place between a superior and subordinate. Communication from a superior to a subordinate comprise mainly of job instructions, job rationale, organizational procedures and practices, response on subordinate performance and indoctrination of goals. On the other hand, communication from subordinate to superior may consist of information about the subordinate, information 
about co-workers, information about organizational policies and information on what needs to be done and how it can be done (Schnake, Dumler, Cochran, \& Barnett, 1990).

Nevertheless, to date, only a few studies have explored how the superior-subordinate relationship (LMX) affects superior-subordinate communication behavior within the organizational context of work groups (Anderson, Tolson, Fields, \& Thacker, 1990; Kramer, 1995; Sias, 1996; Sias \& Jablin, 1995). In explaining the relationship between superior-subordinate, most communication scholars use leader-member exchange theory (LMX) as a basis for their explanations of this dyadic relationship (Lee, 1997). Graen and UhlBien (1995) argue that research involving LMX theory should examine the impact of the LMX relationship on systems of groups and organizations, such as how superior-subordinate communication behavior is related to perceptions of work relationship between group members. Sias and Jablin (1995) reported that work group members were aware of superiors' differential treatments of their co-workers. These findings suggest that perceptions of unfairness may influence superiorsubordinate communication relationships in work groups. Therefore, this research attempts to further explore the relationship between LMX and superior-subordinate communication; and how the superior-subordinate relationship within the work group (vertical associations) affects communication, particularly superior-subordinate communication behaviors between group members (lateral associations).

\section{REVIEW OF LITERATURE}

\section{Leader-Member Exchange}

Superiors are limited in their time and resources and share their personal and positional resources differently with their subordinates for job performances (Graen, 1976; Graen \& Cashman, 1975; Graen \& Scandura, 1978; Graen \& Schiemann, 1978; Graen, Liden, \& Hoel, 1982; Graen \& UhlBien, 1995). Lee and his associates argued that LMX relationship exists on a continuum. As a result, leaders tend to develop and maintain LMXs with their subordinates that vary in quality rang- ing from high (in-group), medium (mid-group) and low (out-group) (Mueller \& Lee, 2002; Lee, 2001; Lee, 1997). High-quality exchange relationships sometimes called in-group, cadre, or partnership, is demonstrated by a high degree of mutual positive affect, loyalty, contribution or obligation to exchange, professional respect, and trust, whereas, the opposite is observed in low-quality exchange relationships sometimes called outgroup, hired hands or manager ship (Liden \& Maslyn, 1998).

Research in LMX indicates that subordinates in high-quality LMX received and reported more favorable outcomes than their peers in lowquality LMX relationships. Duarte, Goodson, and Lich (1994), found that poorly performing, high LMX employees were given favorable ratings, regardless of their actual performance. Moreover, Dienesch, and Liden (1986) discovered that high LMX members consistently received more formal and informal rewards than low LMX members. Low-quality exchange members may experience a sense of unfairness which gives rise to feelings of second-class status (Yulk \& Fu, 1999).

\section{LMX and Superior-Subordinate Communication} Superior-subordinate communication behavior is usually referred to as a process and interaction that is practiced by a superior towards a subordinate with an objective to achieve their task objectives and to maintain relationship (Miles, Patrick, \& King 1996). In an organizational setting, the superior-subordinate communication has been broadly defined as an exchange of information and influence among organizational members and one of these members has an official authority to direct and evaluate the activities of the members of the organization (Jablin, 1979). Clampitt and Downs (1993) define superior-subordinate communication as an upward and downward communication with superiors, including openness to ideas and listening to problems. Katz and Khan (1978), have provided a comprehensive categorization of the types of communication which takes place between a supervisor and a subordinate, which include job instruction, job rationale, procedures and practices, feedback and indoctrination of goals. Based on Katz and Khan's (1978) work, Huseman, Hatfield, Boulton, and Gatewood 
(1980) developed seven types of superior-subordinate communication behavior which include direction, information, rationale, feedback, positive expression, negative expression and participation.

Miles, Patrick, and King (1996) used Huseman et al.'s (1980) work and introduced four separate dimensions of superior-subordinate communication behaviors i.e., positive relationship communication, upward openness communication, negative relationship communication and job-relevant communication. Positive relationship communication focuses on the superior seeking suggestions from subordinates, being interested in them as people, relating to them in a casual manner, and allowing them to contribute input on important decisions. Upward openness communication is characterized by the opportunity to question a superior's instruction and to disagree with a superior. Negative relationship communication deals with the superior ridiculing subordinates and criticizing them in the presence of others.

Job-relevant communication includes a superior's feedback on performances; information includes a superior's feedback on performance, information about rules and policies, job instructions, work assignments and schedules, and goals. These four dimensions according to Alexander, Helms, and Wilkins (1989) generally represent superior-subordinate communication in the organization and have been shown to predict both subordinate job satisfaction and subordinate performance and this has been corroborated by Miles et al., (1996).

Pelz (1952) found that the superior's upward influence moderates the subordinates' satisfaction. Pelz (1952) discovered that the supportive behavior of leaders with high upward influence was related significantly greater to subordinate satisfaction than the supportive behavior of leaders with low influence. This moderating effect of the supervisor's hierarchical influence on members' attitude and behaviors is called the "Pelz Effect" (Jablin, 1980a; 1980b). Jablin (1980a; 1980b) found that when the superior has more upward influence in decisions related to policy matters as well as in work assignment, methods and performance review, the subordinates reported higher levels of satisfaction and openness. A few studies have explored the "Pelz Effect" and have suggested that the LMX quality is likely to affect subordinates' perceptions of superior-subordinate communication behavior between group members (Lee, 1997). Several studies have empirically supported the Pelz Effect (Anderson \& Tolson, 1991; Jablin, 1980a; 1980b). Anderson and Tolson (1991) found that the degree of a leader's hierarchical influence was related to the subordinates' sense of upward control within the organization and their perceptions of support and cooperative behaviors within their groups. Even though these studies are not concerned specifically with the effects of leaders' upward LMX with their bosses on communication between subordinates, but the findings are indicative of potential effects of the Pelz effect on communication behaviors among co-workers in the work group (Anderson \& Tolson, 1991; Lee, 1997).

The differential qualities of LMX have been found to affect a variety of communication behaviors between superiors and subordinates (Fairhurst, 1993; Krone, 1992; Waldron, 1991; Lee \& Jablin, 1995; Lee, 1997; 2001; Mueller \& Lee, 2002, Yrie, Hartman, \& Galle, 2002). Earlier research explicated how the quality of LMX affects subordinates' and superiors' communication areas such as discourse patterns, upward influence, communication expectations, cooperative communication, perceived organizational justice, and decision-making practices (Fairhurst, 1993; Fairhurst \& Chandler, 1989; Jablin, 1987; Krone, 1992; Lee, 1997, 2001; Lee \& Jablin, 1995; Yulk $\& \mathrm{Fu}, 1999)$. Sias and Jablin (1995) reported that the different treatments from superiors to their subordinates affect co-worker communication. Co-workers are aware of the differential treatment and, in fact, talk about it. Furthermore, individual in low versus high quality relationships with their superiors have more conversations about differential treatments with their peers. Sias (1996) also reported that co-worker conversations about differential treatment from their superiors serve to create and reinforce social perceptions about differential treatment in the work group.

Superior interaction patterns in highquality LMX typify "open" communication ex- 
changes (leadership) in which subordinates are afforded greater amounts of trust, confidence, and attention, inside information, negotiating latitude, and influence without resources to authority. In contrast, low-quality LMX are "closed" communication systems (supervision) in which the superior uses formal authority to force members to comply with prescribed roles (Graen \& Scandura, 1987; Jablin, 1987). As a result, subordinates in low-quality LMX are restricted in their opportunities to influence decisions, and, hence complain of their superior's resistance, unresponsiveness, and torpor in their attempts to affect change.

Superiors and subordinates engaged in different levels of LMX display unique aligning, accommodating, and discourse patterns (Fairhurst, 1993), vary in frequency in their communication (Baker \& Ganster, 1985), adopt different persuasive, impression management, or seek the favor strategies to attempt upward influence (Deluga \& Perry, 1994; Krone, 1992; Wayne \& Ferris, 1990; Wayne \& Green, 1993), and utilize different types of conversational resources (Fairhurst \& Chandler, 1989). Research also shows that superiors and subordinates in different LMX engage in varying relational maintenance and communication strategies (Lee \& Jablin, 1995; Waldron, 1991), form different attributions to explain and interpret critical performance incidents (Wilhelm, Herd, \& Steiner, 1993), enact different safety communication (Hofmann \& Morgeson, 1999) and use different amounts of consultation for decision making (Yulk \& Fu, 1999). These results indicate that the quality of LMX leads to different interactional patterns and attitudes between superior and subordinates. LMX quality seems to dictate the type and quality of interact ional pattern, biased heavily in favor of subordinates involved in high quality as opposed to those in low quality LMX relationships.

Thus, members in high quality LMX are likely to have better communication behaviors than their peers in low quality LMXs. Subordinates in high quality LMX expect and enjoy greater openness and frequency in communication, voice and feedback opportunities, participation and involvement in decision making, cooperative and receptive information sharing, and person-oriented message exchanges, which in turn affect superior-subordinates communication behaviors (Lamude \& Daniels, 1995; Lee, 1997). The quality of LMX is also likely to affect subordinates' perception of satisfaction regarding of communication in work group contexts. Findings from several studies suggest that subordinates' perception of exchange quality with their superiors affects peer communication (Kramer, 1995; Lee, 1997; Sias, 1996; Sias \& Jablin, 1995). Sias and Jablin (1995), for example, reported that different treatments from a superior toward subordinates affected co-worker communication. Lee (1997) also reported that the quality of superiors' LMX with their supervisors was positively related to subordinates' perceptions of cooperative communication in the work group. It appears highly likely that superior-subordinate exchange quality affects communication behaviors between group members.

\section{Hypothesis}

The quality of LMX is likely to affect perceived superior-subordinate behavior among subordinates. A few studies have indirectly suggested a link between the quality of LMX and superior communication behavior towards subordinates (Fairhurst, 1993; Krone, 1992; Waldron, 1991; Lee \& Jablin, 1995; Lee, 1997; 2001; Mueller \& Lee, 2002; Yrie, Hartman, \& Galle, 2002). For instance, Yrie et al. (2002) indicated that employees in higher-quality exchange situations should be expected to experience higher-quality communication with the supervisor. Thus, the hypothesis is:

\section{$H$ : The quality of LMX will affect superior com- munication behavior among group members.}

\section{METHOD}

Subjects of this research were primarily employees of a large semi-government corporation and its subsidiary in a northern state in Peninsular Malaysia. Survey packets were sent directly to 317 management employees (under supporting staff categories). 231 respondents ( $72.8 \%$ rate of re- 
turn) returned the survey packets. 64.5 percent (n $=149$ ) were male respondents and 35.5 percent $(\mathrm{n}=82)$ were female respondents. Majority of the respondents $(80.1 \%, \mathrm{n}=185)$ were support staff and the rest $(19.9 \%, \mathrm{n}=46)$ were under the management and professional category. 8.3 percent ( $\mathrm{n}$ $=19$ ) respondents had worked for the organization less than one year, 21.2 percent $(n=49)$ had worked for one to three years, 25.5 percent $(\mathrm{n}=$ 59) had worked between four to six years, 24.7 percent $(n=57)$ had worked between seven to ten years and 20.3 percent $(n=47)$ had worked for more than ten years.

\section{Measurement Instrument}

The measurement of the quality of relationship in this study relied primarily on scales from the LMX theory (Liden \& Graen, 1980). In a review of LMX research, Dienesch and Liden (1986) identified working relationship as perceived contribution (amount, direction, and quality of work-oriented activity), loyalty (voicing support in the presence of third parties) and affect (feelings) with 14 items to measure the working relationship. Each question is measured on a five-point Likert scale. Pretest results for this measurement show Cronbach's alphas that are .87 to .92 . Subjects were asked to indicate the extent to which they agreed with each item on a scale from $1=$ strongly disagree to $5=$ strongly agree. Therefore, scores of LMX quality ranged from 14 to 56, and the higher the score, the higher the quality of LMX. The mean score of LMX in the present study was 36.10 (Median = $36.00, \mathrm{SD}=5.19$ ). Furthermore, an inspection of the frequency distribution indicated approximately three equal proportions. Therefore, the quality of the subordinates was grouped into three levels that is, in-group, middle-group, and out-group (Lee, 1997; 2001; Mueller \& Lee, 2002). A one-way ANOVA test indicated that the three levels of the quality of subordinate's LMX were significantly different from one another, $\mathrm{F}(2,228)=332.78$, $\mathrm{p}$ $<.005$.

The instrument used to quantify superiorsubordinate communication behavior in this present study was adapted from Miles et al., (1996), where the 24 modified items were origi- nally developed by Husemen et al., (1980). These items represent eight types of messages developed by Husemen, et al., (1980). The eight message types are feedback, rationale, information, direction, negative expression, positive expression, participation and upward openness which is represented by three questions per type of message with each question measured on a five-point Likert type scale. Cronbach's alpha for the overall superior-subordinate communication behavior was .82 .

\section{RESULTS}

This research hypothesis was concerned with how the quality of LMX affects perceptions of superior communication behavior among group members. The subjects' responses were analyzed by an ANOVA procedure. Analysis showed that there was a significant effect of the quality of LMX on group superior-subordinate communication behaviors, $\mathrm{F}(2,228)=5.09, \mathrm{p}<.005$ (see Table 1). Lee's $(2001,1997)$ research had indicated that members of in-group LMXs perceived significantly higher satisfaction of supervisory communication than their middle-group counterparts who in turn, reported significantly greater amounts of supervisory communication satisfaction than their out-group peers. Therefore the Bonferroni multiple comparison was used (Pagano, 2001). Results of the Bonferroni multiple comparison test (see Table 2) indicate that perceptions between members of the out-group when compared with members of the middle and in-group indicates no differences on superior communication behavior. The results also show that there are no significance differences of perception of their superior communication behavior between the middle-groups and the in-group and out-group. Further analysis of the in-group as compared to middle and outgroup shows that there is no significance difference between the in-group and out-groups ( $\mathrm{t}(299)$ $=1.47, \mathrm{p}>.05 ; \mathrm{t}(299)=-4.53, \mathrm{p}>.05)$, but when compared between their counterparts in the middle-group, the results indicate that there is significance difference with regards to their superior communication behavior, $\mathrm{t}(229)=6.01, \mathrm{p}<.05$. 
Table 1:

Analysis of Variance

\begin{tabular}{lcrcc}
\hline & Sum of Squares & df & Mean Squares & F \\
\hline Between Group & 417.11 & 2 & 208.56 & $5.09 *$ \\
Within Groups & 9348.22 & 228 & 41.001 & \\
Total & 9755.33 & 230 & & \\
\hline
\end{tabular}

$* \mathrm{p}<.05$

Table 2:

Mean Difference between Group Members

\begin{tabular}{llll}
\hline Group & Mean 1 & Mean 2 & Mean 3 \\
\hline Out-group (1) & - & 1.478 & 4.533 \\
Mid-group (2) & - & - & $6.01^{*}$ \\
In-group (3) & & & - \\
\hline
\end{tabular}

$* \mathrm{p}<.05$

\section{DISCUSSION}

The hypothesis deals with the effects of LMX on superior communication behavior and as predicted, the one-way ANOVA test indicates that the quality of LMX positively affected how subordinates perceived their superiors' communication behavior. The higher the quality of LMX, the more subordinates reported higher level superior communication behavior. This finding is consistent with the theoretical perspective and empirical discoveries of LMX and communication behaviors and activities in the superior-subordinate relationship. Subordinates in high quality relationship enjoy a higher quality positive relationship communication, upward openness communication, and job-relevant communication. In addition to these they also experience less negative relationship communication (Graen \& Uhl-Bien, 1995; Yrie et al., 2002). As a matter of fact, the quality of LMX appears to correlate with how individual subordinates feel about their communication experiences. Additionally, findings from this study indicate that the quality of LMX affects perceptions of superior communication behavior between group members in an organization.
Furthermore, these findings have important implications for leadership roles, especially leaders' behavior towards subordinates. Leaders are constrained in their resources and develop discriminatory LMXs with their subordinates, which in turn affect perceptions of their behavior towards subordinates (Graen \& Uhl-Bien, 1995; Lee, 1997; 2001). In this regard, leaders may build unfairness into work relationships with their subordinates. As mentioned by Lee (2001), the quality of LMX is likely to be structured by different communication rules and resources over time, and therefore subordinates in low-quality LMXs are likely to hold long term perceptions of greater unfairness in the organization, which may affect effective functioning of organizations, including superior communication behavior (Lee, 1997; 2001).

The LMX theory suggests that superiors distribute their resources unequally to their subordinates, thus some subordinates receive more resources than their peers. It is safe to say that the higher the quality of LMX, the higher the number of subordinates who reported higher levels of communication quality from their superiors. In other words, subordinates in the in-group should per- 
ceive the superior communication behavior differently from subordinates in the mid-group and the in-turn perceived differently from the outgroup. However, results of the current study indicate that there is no significance difference of perception between subordinates in the in-group and out-group, but there is a significant difference of perception of superior communication behavior between the in-group and mid-group.

The LMX theory has historically emphasized the discovery of differentiated dyads which are concerned with distinguishing in-group employees from those in the out-group and identifying the degree to which the in-group receives a different level of supervision in terms of freedom from close supervision and negotiating latitude (Gerstner \& Day, 1995). According to Gerstner and Day (1995), the next phase of the LMX theory emphasizes on the exchange itself, in terms of discovering its quality and consequences. Up to this point however development was primarily descriptive rather than prescriptive and mainly paid attention to describing the functioning of the dyad rather than focusing upon how dyads should operate. Potential troubling findings have surfaced; especially in-group or out-group status may occur early in the life of the dyad and may be opposed to change (Dienesch \& Liden, 1986; Graen \& Cashman, 1975). It is possible that the group existing in the organization may be influenced by the demographic factors and effective similarities (presumably leading the dyad to feel comfortable or compatible) rather than upon 'rational,' business-related grounds (Yrie et al., 2002; 2003). Even though this study reports different findings of work groups perceptions, it is wise to consider Gerstner and Day's (1995) concern about measurement issues and an additional study is needed in this area. It may also imply that measurement adapted from western scholars either on LMX or superior-subordinate communication may not suitable in Malaysia's organization.

\section{CONCLUSIONS AND SUGGESTIONS}

Findings reported in this study have important practical and theoretical implications. The LMX theory suggests that superiors are largely respon- sible for the development of their superior-subordinate exchange relationships (Dansereau et al., 1975; Graen \& Scandura, 1987; Graen \& UhlBien, 1995). Accordingly, superiors enforce communication experiences that subordinates will have by developing and sustaining different LMXs and thus, are primarily responsible for subordinates' affective responses to them. Therefore, to increase an effective communication among their subordinates, superiors should offer opportunities to develop and maintain higher-quality LMXs with as many subordinates as possible (Mueller $\&$ Lee, 2002). For example superiors can increase feedback on work done by subordinates, have more upward communication and practice open communication with all subordinates regardless of their relationship quality.

Subordinates, too can learn and actively engage in communication behaviors that positively affect the quality of LMX with their superiors. They could provide greater competence and performance in tasks by asking for feedback on their performances from their superiors, do things that may increase liking and trust and utilize impression management strategies (Muller \& Lee, 2002). Even though the results of these findings do not support the previous findings on LMX, but by improving the quality of LMX with superiors, subordinates are likely to experience more informal rewards.

The key issue that arises from this study on matching communication behavior to subordinates' needs becomes evident from concerns that the in-group, mid-group and out-group may not occur on objective grounds. Rather, it could be based upon non-objective grounds such as demographic similarity. The results in this area are encouraging in that no evidence was found that the higher-quality dyads were more similar than others in terms of the limited demographics considered (Yrie et al., 2002; 2003). This however, is the area which needs to be studied further. Other demographics factors such as gender, race, age, work experience and job type, could also be contributing factors. Such additional research can play an important role in developing an understanding about when and whether superiors or managers should deviate from "best" communication behaviors. 


\section{REFERENCES}

Alexander, E. R., Helms, M. M., \& Wilkins, R. D. (1989). The relationship between supervisory communication and subordinate performance and satisfaction among professionals. Public Personnel Management, 18, 415-428.

Anderson, L. R., \& Tolson, J. (1991). Leaders' upward influence in the organization: Replication and extensions of the pelz effect to include group-support and selfmonitoring. Small Group Research, 22, 59-75.

Anderson, L. R., Tolson, J., Fields, M. W., \& Thacker, J. W. (1990). Extension of the pelz effect: The impact of leader's upward influence on group members' control within the organization. Basic and Applied Social Psychology, 11, 19-32.

Baker, D. D., \& Ganster, D. C. (1985). Leader communication style: A test of average versus vertical dyad linkage models. Group \& Organization Studies, 10, 242259.

Clampitt, P. G., \& Downs, C. W. (1994). Employee perceptions of the relationship between communication and productivity : A field study. The Journal of Business Communication, 30, (1), 5-29.

Danserau, F., \& Markham, S. E. (1987). Superior-subordinate communication. Multiple level analysis. In F. M. Jablin, L. L. Putnam, K. H. Roberts, \& L. W. Porter (Eds.)

Handbook of organizational communication: An interdisciplinary perspective 343-388. Newbury Park : Sage Publication.

Dansereau, F., Graen, G. B., \& Haga, W. J. (1975). A vertical dyad linkage approach to leadership within formal organizations: A longitudinal investigation of the role making process. Organizational Behavior and Human Performance, 15, 278-296.

Deluga, R. J., \& Perry, T. J. (1994). The role of subordinate performance and ingratiation in leader-member exchanges. Group and Organization Management, 19, 67-86.

Dienesch, R. M., \& Liden, R. C. (1986). Leadermember exchange model of relationship: A critique and further development. Academy of Management Review, 11, 618-634.

Duarte, N. T., Goodson, J. R., \& Lich, N. R. (1994). Effects of dyadic quality and duration on performance appraisal. Academy of Management Journal, 37, 499-521.

Fairhurst, G. T., \& Chandler, T. A. (1989). Social structure in leader-member interaction. Communication Monographs, 56, 215239.

Fairhurst, G. T. (1993). The leader-member exchange patterns of women leaders in industry: A discourse analysis. Communication Monographs, 60, 321-351.

Gerstner, C. R., \& Day, D. V. (1995). Putting leadership back into leader-member exchange: A meta-analytical review and extension. Paper presented at the $10^{\text {th }}$ annual conference of the Society for Industrial-Organizational Psychology, Orlando, FL.

Graen, G. B. (1976). Role-making process within complex organizations. In M. D. Dunnette (Eds.), Handbook of industrial and organizational psychology 12011245. Chicago : Rand McNally.

Graen, G. B., \& Cashman, J. (1975). A role-making model of leadership in organizations: A development approach. In J. G. Hunt, 
\& L. L. Larson (Eds.), Leadership frontiers. 143-165. Kent OH : Kent State University Press.

Graen, G. B., \& Scandura, T. A. (1987). Toward psychology of dyadic organizing. In B. M, Staw \& L. L. Cummings (Eds.), Research in organizational behavior 9,175 208. Greenwich, CT : JAI Press.

Graen, G. B., \& Schiemann, W. (1978). Leadermember agreement: A vertical dyad linkage approach. Journal of Applied Psychology, 63, 206-212.

Graen, G. B., \& Uhl-Bien, M. (1995). Relationship-based approach: Development of leader-member exchange (LMX) theory over 25 years: Applying a multi-level multi domain perspective. Leadership Quarterly, 6, 219-247.

Graen, G. B., Liden, R., \& Hoel, W. (1982). Role of leadership I the employee withdrawl process. Journal of Applied Psychology, 67, 868-872.

Hofmann, D. A., \& Morgeson, F. P. ( 1999). Saftey-related behavior as a social exchange: The role of perceived organizational support and leader-member exchange. Journal of Applied Psychology, 84, 286-296

Huseman, R. C., Hatfield, J. D., Boulton, W., \& Gatewood, R. (1980). Development of a conceptual framework analyzing the communication-performance relationship. Proceedings of the Academy of Management, 178-182.

Jablin, F. M. (1979). Superior-subordinate communication: The state of art. Psychological Bulletin, 86, 1201-1222.

Jablin, F. M. (1980a). Subordinates sex and superior-subordinate status differentiation as moderators of the Pelz Effect. In D. Nimmo (Ed.), Communication Yearbook,
4,327-347. New Burnswick, NJ : Transaction.

Jablin, F. M. (1980b). Superior's upward influence, satisfaction, and openness in superior-subordinate communication: A reexamination of the "Pelz Effect". $\mathrm{Hu}$ man Communication Research, 6, 210220.

Jablin, F. M. (1987). Organizational entry, assimilation, and exit. In F. M. Jablin, L. L. Putnam, K. H. Roberts, \& L. W. Porter (Eds.), Handbook of organizational communication : An interdisciplinary perspective (pp. 679-740). Newbury Park : Sage Publication.

Jablin, F. M., \& Krone, K. J. (1994). Task/work relationship: A life-span perspective. In M. L. Knapp \& G. R. Miller (Eds.), Handbook of interpersonal communication $2^{\text {nd }}$ ed., 621-675. Beverly Hills, CA: Sage.

Katz, D., \& Kahn, R. L. (1978). The social psychology of organizations $2^{\text {nd }}$ ed. New York : Wiley.

Kramer, M. W. (1995). A longitudinal study of superior-subordinate communication during job transfers. Human Communication Research, 22, 39-64.

Krone, K. J. (1992). A comparison of organizational, structural, and relationship effects on subordinates' upward influence choices. Communication Quarterly, 40, 1-15.

Lamude, K. G., \& Daniels, T. D. (1995). Subordinates' satisfaction with communication and manager's relational messages. Perceptual \& Motor Skills, 81(2), 467-472.

Lee, J. (2001). Leader-member exchange, perceived organizational justice, and cooperative communication. Management Communication Quarterly, 14, 574-589. 
Lee, J. (1997). Leader-member exchange, the 'Plez Effects' and cooperative communication between group members. Managerial Communication Quarterly, 11, (2), 266-287.

Lee, J., \& Jablin, F. M. (1995). Maintenance communication in superior-subordinate work relationship. Human Communication Research, 22, (2), 220-258.

Liden, R. C., \& Maslyn, J. M. (1998). Multidimensionality of leader-member exchange: An empirical assessment through scale development. Journal of Management, 24 (1), 43-73.

Liden, R. C., \& Graen, G. (1980). Generalizability of the vertical dyad linkage model of leadership. Academy of Management Journal, 23, 451-465.

Miles, E. W., Patrick, S. L., \& King, W. C. (1996). Job level as systematic variable in predicting the relationship between supervisory communication and job satisfaction. Journal of Occupational and $\mathrm{Or}$ ganizational Psychology, 69 (3), 277289.

Mintzberg, H. A. (1978). Patterns in strategy formation. Management Science, 24, 934948.

Mueller, B. H., \& Lee, J. (2002). Leader-member exchange and organizational communication satisfaction in multiple context. The Journal of Business Communication, 39 (1), 220-244.

Pagano, R. R. (2001). Understanding statistics in the behavioral sciences. Belmont, CA: Wadsworth.

Pelz, D. (1952). Influence: A key to effective leadership in the first line supervisor. Personnel, 29, 209-217.
Schnake, M. E., Dumler, M. P., Cochran, D. S., \& Barnett, T. R. (1990). Effects of differences in superior and subordinate perceptions of superiors' communication practice. The Journal of Business Communication, 27 (1), 37 - 48.

Sias, P. M. (1996). Constructing perceptions of differential treatment: An analysis of coworkers discourse. Communication Monographs, 63, 171-187.

Sias, P. M., \& Jablin, F. M. (1995). Differential superior-subordinate relations, perceptions of fairness, and coworker communication. Human Communication Research, 22, 5-28.

Waldron, V. R. (1991). Achieving communication goals in superior-subordinate relationships: The multi-functionality of upward maintenance tactics. Communication Monographs, 58, 289-306.

Wayne, S. J., \& Ferris, G. R. (1990). Influence tactics, affect, and exchange quality in supervisor-subordinate interactions: A laboratory experiment and field study. Journal of Applied Psychology, 75, 487499.

Wayne, S. J., \& Green, S. A. (1993). The effects of leader-member exchange on employee citizenship and impression management behavior. Human Relations, 46, 14311440.

Wilhelm, C. C., Herd, A. M., \& Steiner, D. D. (1993). Attributional conflict between managers and subordinate : An investigation of leader-member exchange effects. Journal of Organizational Behavior, 14, 531-544.

Yrie, A. C., Hartman, S., \& Galle, W. P. (2002). An investigation of relationship between communication style and leader-member exchange. Journal of Communication Management, 6 (3), 257-269. 
Yrie, A. C., Hartman, S., \& Galle, W. P. (2003). Examining communication style and leader-member exchange: Considerations and concerns for managers. International Journal of Management, 20 (1), 92-101.
Yulk, G., \& Fu, P. P (1999). Determinants of delegation and consultation by managers. Journal of Organizational Behavior, 20, 219-232. 